УДК 791.229.2:39(497.723)(049.3)

https://doi.org/10.55302/MF2077-78245k

Елизабета Конеска

\title{
ПРЕДИЗВИКОТ НА ВИЗУЕЛНОТО ИЗРАЗУВАЊЕ И НЕГОВИТЕ ПЕРСПЕКТИВИ НИЗ ПРИЗМАТА НА МЕГ์УНАРОДНИОТ ФЕСТИВАЛ НА ЕТНОЛОШКИ И НА ДОКУМЕНТАРНИ ФИЛМОВИ ВО КРАТОВО
}

Апстракт: Единствените места кај нас, каде што се презентираат етнолошки филмови, кои ја откриваат и ја доближуваат реалноста на обичниот поединец или на одредена заедница во состав на социокултурниот и на историскиот контекст на општеството, со племенитата мисија на раскажување со глас и со слика, се главно фестивалите. Еден од нив е Меѓународниот фестивал на етнолошки документарен филм во Кратово, кој постои од 2012 година.

Клучни зборови: етнолошки филм, состојба, перспективи, фестивал, Кратово.

Етнолошките истражувања артикулирани преку визуелното изразување, форматирани во етнолошки филм, имаат за цел што повидливо, со слики, да ја откријат и да ја доближат реалноста на обичниот поединец или на одредена заедница во состав на социокултурниот и на историскиот контекст на општеството.

На почетокот на создавањето и на дефинирањето на етнолошките филмови, во средината на 20 век, се верувало дека тие во иднина ќе придонесат за подобро разбирање меѓу културите и за почитување на културните разлики. Денес, потенцијалот на етнолошкиот филм сѐ повеќе се гледа во можноста да биде реализиран како дел од применетата јавна и визуелна антропологија: „Визуелните методи и медиуми сѐ повеќе се прифатени и се популарни во сите „етнографски“ дисциплини, а јазот помеѓу пишаната и академска антропологија се стеснува“ (Пинк, 2011, 9). Продукцијата на филмови е сѐ побројна, а повеќедецениската заложба на релевантни автори од оваа област придонесе со сѐ поблиското вреднување на визуелната етнологија, односно приближувањето на филмот на рамниште на теориската рамка (Руби, 2015, 44; интернет-извори).

Фестивалите на кои се прикажуваат овие филмови од чии содржини се запознаваме со животи и судбини на поединци и на групи од различни културни средини од познати до најнедопирливи места ширум светот, сѐ до непосредните наши соседства, се речиси единствени места кај нас, каде што се презентира племенитата мисија на раскажување со глас и со слика.

Меѓународниот фестивал на етнолошки документарен филм во Кратово постои од 2012 година. По осум години, освен тоа што можеме да се пофалиме дека во Македонија постои меѓународен фестивал на етнолошки филм, можеме и да констатираме дека достигна свое реноме со кое се вклучи во листата на добрите и на познатите фестивали не само во регионот, туку и во Европа и пошироко. 
Програмата, секоја година, содржи филмови од меѓународна продукција, од нашето регионално опкружување, како и филмови од домашна продукција.

\section{Учесници на Меѓународниот фестивалот на етнолошки документарен филм во Кратово}

Досега, повеќе светски еминентни автори од визуелната антропологија биле присутни на Фестивалот во Кратово како автори на филмови или како познавачи и презентери на значењето на етнолошките филмови, односно на визуелната антропологија.

Од попознатите имиња во регионот неизбежно треба да се споменат: Асен Баликчи (еден од доајените на светската етнологија - од Бугарија), Нашко Крижнар и Надја Фурлан - од Словенија; Алексеј Павловски, Иво Кузманиќ, Љиљана Шишмановиќ, Давор Бориќ - од Хрватска; Владимир Перовиќ, Слободан Наумовиќ - од Србија. Гости од Европа биле: Колет Пјо од Франција; Стеф Мајнехт - од Холандија; Џовани Кезиќ, Антоанела Мот од Италија; Сара Пинк, Мартин Грубер - од Германија; Иван Головнев - од Русија; Ливо Ниглас - од Естонија; Фроде Сторас - од Норвешка; Питер Крафорд - од Данска и Гери Килдеа - од Австралија.

Предавачи на првиот Фестивал во Кратово, во 2012 г., беа Нашко Крижнар од Словенија и Радослава Ганева од Бугарија, и обајцата зборуваа за состојбите на визуелната етнологија во својата земја. Присуството на најзначајното име за визуелната етнологија во регионот, Н. Крижнар, значаен филмски работник, основач на Аудиовизуелната лабораторија при Словенечката академија за науки и професор по визуелна етнологија на Универзитетот во Копар, воедно значеше и голема поддршка за нашиот Фестивал (Конеска, 2015, Нашко, 262).

На вториот, по ред, Фестивал, во 2013 г., предавачи беа Џовани Кезич од Италија и Тања Буковчан од Хрватска, кои преку личните искуства зборуваа и за организираното создавање и презентирање на визуелната етнологија. Додека на третото издание на Фестивалот, во 2014 г., главно за личните искуства при создавањето на филмот зборуваа Колет Пјо од Франција, една од доајените на француската визуелна антропологија и Стеф Мајнехт, извонреден визуелен антрополог од Холандија.

Во 2016 г., како искусни автори на филмови за состојбата со визуелната антропологија во својата земја зборуваа Мартин Грубер од Германија и Владимир Боцев од Македонија. Следната, 2017 г., свое предавање имаше Питер Јан Крафорд од Данска, претседател на НАФА, асоцијацијата за визуелна антропологија од нордиските земји.

На седмиот, по ред, Фестивал, во 2018 г., група помлади автори од Бугарија (Димитар Василев и Атанаска и Тодор Станчеви), зборуваа за Фестивалот на етнографски филм во Софија, кој е една година помлад од Фестивалот во Кратово. Предавачи на теми од споменатата област немаше на четвртиот, во 2015 г., и на осмиот Фестивал во 2019 г. 


\section{Фестивалот}

Критериумите што се применуваат за избор во програмата на Фестивалот се однесуваат на тоа филмовите да ги содржат неопходните компоненти од етнолошко-антрополошка тематика, да се драматуршки издржани и да се визуелно и технички коректни. Според тематиката некои од филмовите се блиски до локалната и до регионалната култура, а други се бираат со сосема спротивна цел - да се покажат различности од подалечни и помалку познати култури. Една од предностите во селекцијата на филмовите на овој Фестивал е тоа што годината на производство на филмовите не е ограничена, што е својствено на поголем број фестивали за етнолошки и документарни филмови. Иако најголем број од филмовите во програмата на Фестивалот во Кратово се главно од понова продукција на визуелна етнологија и антропологија, сепак, со прикажување и на постари продукции се отвораат поголеми можности. Прикажувањето на различни автори, на добри стари продукции на етнолошки филмови, овозможува компаративни анализи, па дури и реконструирање на одредени појави и процеси (Конеска, 2015, 124).

Селекцијата на филмовите на фестивалот во Кратово и годинава, како и во изминатите години, ја прави Владимир Боцев, кој е иницијатор и главен организатор на Фестивалот. На Боцев, како искусен и најпознат визуелен етнолог од Македонија, во селекцијата, од понудените во просек меѓу 60 и 80 филмови, повремено му се приклучува и неговиот главен поддржувач и соработник Зоранчо Малинов, актуелен Претседател на Македонското етнолошко друштво.

Првичната идеја на организаторите, Фестивалот да се одржи во Кратово, покрај практичните причини, била и желбата да се анимира и да ѝ се овозможи, на публиката од помалите места, да се запознае со жанрот на документарно-етнолошкиот филм (Боцев, 2013, 217). Идејата Фестивалот секоја година да се одржува во различни градови низ државата, веројатно од истите практични причини, не се оствари. Сепак, изборот на Кратово се покажа како солиден, веројатно и заради добрата соработката меѓу Музејот, Општината и организаторот. Една од предностите на одржувањето на фестивалите во помалите места се топлите и човечки релации што се создаваат меѓу домаќините, гостите и учесниците, каков што е и примерот со Кратово.

\section{Програма}

Оваа, 2019 година, во периодот од 27 до 29 септември се одржа осмиот, по ред, Фестивал. Во текот на неполни три дена беа прикажани 24 филмови од 20 различни земји (Хрватска, Романија, Индија, Велика Британија, Полска, Србија, САД, Русија, Иран, Грција, Парагвај, Германија, Јапонија, Белгија, Бразил, Бугарија, Италија, Шпанија, Норвешка и Македонија). Годинава на Програмата на Фестивалот, прикажаните филмови одеа по следниот редослед: „Летечкиот фратар“, хрватска продукција, од режисерот Давор Бориќ, кој заедно со колешката Лилјана Шишмановиќ се најредовните автори на 
репертоарот на Фестивалот во сите изминати години. Овој пат се претставија со многу инспиративната приказна за ликот на фратарот, како свештено лице и како етнолог. Филмот „Полиња со јагоди“, од Романија, во режија на Симон Фреј и Присила Расид, ни ја прикажа активноста на самохраната мајка Ленуца, од малиот град под Карпатите. Во „Чидра“ од Надав Харели од Индија го гледавме ликот на Рам Нат во ритуалот на прочистување во химелајската долина Кулу. „Активен (Граѓанин)“ од авторите Пјотр Голдстајн и Јан Лоренц (продукција на Велика Британија, Полска и Србија) е ведар филм со интимен поглед на животот и работата на бегалец, Ром од Косово, кој е собирач на ѓубре во Нови Сад. Од авторката Светлана Стасенко (продукција на Русија и САД) е филмот „Шаманска лекција за почетници“, во кој го гледаме чудното заемно пријателство меѓу шаманот, возрасниот Чочагар Кескем и американскиот психолог Алекс, кој дошол во Тува да учи за шаманистички практики. Филмот „Упорниот поштар“, од режисерот Арман Гхолипур Даштаки од Иран, зборува за Ханали, 92-годишен поштар, кој не може да прифати дека по 35 години, тој е ослободен од работа. Филмот од Грција, од авторите Роза Геларди и Софи Крабе, „УН (Перење)“, е кусо, но интересно согледување за подвижната перална за бездомниците во Атина и двосмисленото значење на поимите „чистота“" и „нечистотија“. „Јујос“, во режија на Михал Кравлик и Џукија Лепори од Парагвај, го документира секојдневниот живот и етноботаничкото знаење на семејството Франко Гауто. Тие се дел од етнографски проект спроведен во месноста Колонија Луз Бела во Парагвај. Филмот на Мартин Грубер (визуелен антрополог од Германија) и Рика Шинкаи (од Јапонија), „Првата берба“, покажува дел од активностите на Клубот за пчеларство, при Кјото-универзитетот за уметност и дизајн. Во филмот „Храмот Кали од внатре и од надвор“, на Дипеш Карел и Фроде Сторас од Норвешка, се запознаваме со уште еден индиски храм од градот Канпур, Утар Прадеш, но овој пат гледано посуптилно и од поинаков агол, и од внатре, и од надвор. Преку интимните приказни на неколкуте протагонисти се наметнува вистината дека религиозните граници не се неопходни толку антагонистични колку што медиумите знаат да ги прикажат тоа. „Сувите докови“, од Либе Вилкленс од Белгија, е филм за сервисери на бродови и секојдневието, и приврзеноста со тешката работа што се случува во доковите во Антверпен. „Теленгитите, номади на 21 век“, од Алексеј Борисов од Русија, прикажува неколку денови живот на современ номадизам на Ајдар и овчарот Роберт Чапович на планината во огромниот Алтај. Иранскиот филм „Љубените“, од режисерот Јасер Талеби, е поглед на животот на Фирузе, енергична и храбра 82-годишна жена, која, без електрична енергија и без телефонска комуникација, живее во планина во Северен Иран и се грижи за стадо крави. „Традиционалното бразилско семејство Кату“ од Родриго Сена, од Бразил, е фотографски есеј, кој прикажува дванаесет адолесценти од домородното население Елеутерио до Кату, за повторно да ги запознае нивните животи со враќање кај нив по дванаесет години. Филмот од Бугарија, од Ралица Димитрова, е интересен приказ за уништена фабрика и за напорот на Методи да ги зачува спомените, насловен како „Сентиментална приказна“. Рускиот филм „Јас сум Виктор“, од Ина Цгоева, е трогателна сторија за 
осамениот Виктор. „Пеењето“, руско-полски филм од Олга Короткаја, е филм за традиционално машко пеење кхумеј, од жителите во руската република Тува. Вања Матеева од Бугарија, преку видеозаписи од теренските истражувања, со филмот „Тркалото на животот“, дава преглед на социокултурниот живот на слепите луѓе во својата земја. „Звучни портрети“ од Паоло Винати, од Италија, е филм за новите пеења и за јазиците што ечат на планините на Доломитите од луѓето што емигрираат од различни причини, за љубов, за лична безбедност, во потрага по работа. Грчкиот филм од Катерина Маркулаки, „Врати се од барот“, низ поинаква филмска призма, следи група млади луѓе зафатени од грчката економска криза. Ги истражува динамичните потенцијали на супкултурата што беснее во Атина, а следејќ ги нивните забави, прави обид да ги препознае и меланхоличните аспекти на крајната потрага по слобода. Славко Горгиев, со единствената визуелна презентација од Македонија - „Мали мостови“, го документира реконструираниот обичај на правење минијатурни мостови од гранки, кој се практикувал на 22 март во селото Ораовица, Штипско. Последните прикажани два филма од Програмата на овогодишниот фестивал беа многу суптилно изработени аспекти на животните приказни на две возрасни жени, едната од Шпанија, другата од Италија. Филмот „На нејзиното тело“ од Едурне Урестаразу Гарсија од Шпанија, која, следејќи ја телесната маршрута на 89годишната Имилце Естер, нејзината баба, преку секојдневно, дури, банално движење, е покажана нивната заемна емотивна блискост. „Богородица на морето - невеста на морето“, од Валентина Ланци од Норвешка, е филм за Ана Марија, која, од мала е риболовец на Јадранското Море, а денес е најстарата рибарка со своите 83 години. Во овие два филма беше препознатлив ракописот на познатата нордиска школа за визуелна антропологија, кои беа пример за успешно антрополошко визуелно изразување. Од авторките, двете присутни на фестивалот, беше задоволство да се чуе искуството и сознанијата што ги стекнале низ школувањето и низ работењето на своите извонредни почетнички филмови. Поради технички проблеми не беше прикажан само последниот филм од Програмата, рускиот филм „Изворот на душата““ од Алексеј Обухов, посветен на уметник Валентин Димитриевич Шевелев, почесен граѓанин на градот Каргопол, чувар на традицијата и на играчките од глина.

Меѓународната продукција на програмата беше вообичаено шареновидна и по тематика и по земји на снимање. Правењето на етнолошки филмови во Македонија, за жал, како повторно да е во застој. Сѐ уште Македонија не може да се пофали со нови автори и нови квалитетни продукции, за што се надеваме дека е само привремено. 


\section{Актуелната состојба на фестивалот}

Покрај сите наведени позитивни согледувања и пофалби за Фестивалот во Кратово, тој сепак се соочува со најголемиот проблем, особено последните години, а тоа е отсуство на побројна публика. На проекциите на филмовите во дводневниот фестивал редовна публика се главно дел од организаторите и неколкумината гости автори. Извесно е дека не само кај нас, туку и пошироко, публика на фестивалите на етнолошки-антрополошки филмови прилично тешко се обезбедува. Особено е интересно што секогаш има малку колеги етнолози и антрополози, или познавачи на филмот. Состојбата со намалувањето на бројот на публика на фестивалите, од овој тип, за жал има општ тренд на опаѓање и на останатите во регионот и пошироко. Постарата публика си оди, а регрутирањето на помладата публика е многу слабо. Ваквата тенденција веројатно се должи и на осиромашувањето на општествата, лошиот образовен систем, на општата атмосфера на криза во културата, односно на сѐ помалиот број партиципиенти за културни потреби. Како да е изгубен социјалниот момент на дружењето на публиката во киносалите. Освен инцидентно и за поединечни филмови, денес се гледаат филмови, главно, преку компјутер или во состав на пазарењето, „шопингот“, во кината во трговските центри.

За подобрување на состојбата е неопходно зголемување на активностите, но и одредени промени. Зголемувањето треба да биде со поголема медиумска кампања, со информирање преку класичните медиуми и социјалните мрежи. Треба да има и подобрување на меѓуинституционалната соработка, со други музеи, институти и секако со Катедрата по етнологија. Вклучувањето нови, помлади членови во организацијата, би помогнало во рушење бариери и надминување стереотипи, што би придонело за популарноста на овој вид филмови и за фестивалот во Кратово.

Тоа го потврдуваат и искуствата на колегите од соседството, основачите на два веќе етаблирани и меѓуннародно авторизирани манифестации, Саша Сречковиќ од Меѓународниот фестивал на етнолошки филм од Белград (годинава - 28, по ред) и Нашко Крижнар, основачот на ДЕФ (Деновите на етнографски филм во Љубљана) - со деветгодишно искуство. Проблемот на недостиг на публика организаторите на овие Фестивали се обидуваат да го решат со поголемо вклучување на млади колеги како и со интензивно медиумско популаризирање.

Како и останатите филмски фестивали и фестивалите на етнолошките документарни филмови треба „да живеат“ во текот на целата година. Прикажување на филмовите во текот на годината во други градови, како и во Скопје, секако дека би дало свој придонес за нивно популаризирање. Потоа, организирање работилници во периодот пред одржувањето или во текот на Фестивалот, за почеток е доволно да биде тоа и со ученици во самиот град Кратово. Секако и подобрување на соработката и враќањето на довербата на студентите од Катедрата за етнологија и антропологија од Универзитетот „Св. Кирил и Методиј“ од Скопје, кои, во првите години, доаѓаa организирано на Фестивалот. Овие студенти од пред пет години, заедно со Илина Јакимовска, 
професорката по предметот визуелна антропологија на Катедрата, организираат Меѓународен фестивал на етнолошки филмови „Етнофф“, кој се одржува во Скопје и веќе има развиено меѓународна и регионална мрежа на соработка со студенти. Не би го исклучила фактот дека за појавувањето и за популарноста на „Етнофф“, свој придонес дал и Фестивалот во Кратово.

Не е помалку значајна, веројатно, и потребата на обезбедување повеќе финансии од соодветните министерства - Министерството за култура, Министерството за образование и наука, од Агеницијата за филм, но и од невладини организации, па веројатно и од меѓународни организации.

За зголемувањето на интересот и за мотивирањето за гледање филмови кај стручните лица и кај колегите, би придонеле и квалитетни продукции на соодветни теми од домашни автори, како и нивна заемна информираност и координираност.

Во овој контекст би го споменала и примерот со совпаѓање на термините на отворањето на Фестивалот во Кратово, во 2019 г., како и одржувањето на Конференцијата, на тема: „Етнолошки и фолклористички аспекти на мултикултурализмот и интеркултурализмот на македонското општество“. Беше необично совпаѓањето меѓу темата на конференцијата и содржината на првиот филм во програмата, „Летечкиот фратар“, од хрватската продукција. Главниот протагонист во филмот, фратарот, е свештено лице, кое комуницира со сите останати религиозни припадници во Босна и Херцеговина. Со својот природен талент тој ги обединува и ги организира во различни културни активности, а додатно, со професионалната љубов, како етнолог, собира и заштитува предмети од локалното културно наследство. Филмот е пример за обединување на квалитети на филмскиот јазик и сликање на портрет на исклучителен духовник и етнолог. Но, ова тематско и содржинско совпаѓане на конференичјата и на филмот со кој се отвори осмиот, по ред, Фестивал во Кратово, за жал беше само случајност. Доколку се реализираше гледањето на филмот со учесниците на конферениијата, ке можевме да се пофалиме дека, како стручни лица, сме дале придонес во примената на филмот и на неговата улога во опитествените и во научните текови. Со тоа би турнале една бариера и би го поддржале значењето на филмовите со ентнолошко-антрополошки содржини, чија иднина сѐ повеќе се гледа како фактор во општествените ангажирања (Пинк, 8). Од мноштвото квалитетни филмови, прикажани на Фестивалот во Кратово, како пример на општествено ангажирање би го посочила филмот од италијанско-британска продукција, „Одржливо земјоделство“ (кој беше прикажан на Фестивалот во 2018 г.), во кој се презентира секојдневниот живот на луѓе, чија желба и определба е да живеат на село и да имаат свое производство, што би било и темел за нивна самоодржливост. Но, дури и во едно средено општество, какво што е Италија, практиката покажува дека има многу предизвици и општествени препреки со кои протагонистите од филмот, производители на здрава храна, се соочуваат. Сепак, во текот на снимањето, особено со прикажувањето на филмот во јавноста, тие успеваат да добијат поголем број приврзаници и својот проблем да го актуелизираат и да го проблематизираат во општеството и на повисоки 
истанции. Во оваа тема препознавме и слични состојби кај нас, при што разменивме мислења со авторот и еден од протагонистите на филмот, кои беа присутни на фестивалот. Таков е примерот од нашето секојдневие, кое се случува на отворено, на познатиот Бит-пазар, и размислувањето како да се подобрат условите за овие индивидуални производители на здрава храна, како да се помогне тие да добијат подобри услови во општеството, а со тоа да се олесни релацијата производители и консумери.

Овде доаѓаме до потврдување на ставот дека етнолошкиот филм е процес, а како таков, тој може да биде и фактор во општествените ангажирања. Можноста и потребата за наменско правење тематски етнолошки филмови, освен во популаризирање на овој медиум, може да даде и практичен придонес во оштествените интервенции.

\section{ЛИТЕРАТУРА}

\section{Кирилични изданија}

Боцев, В. (2013). Прв Меѓународен фестивал на етнолошкиот документарен филм во организација на Македонското етнолошко друштво - „Кратово 2012“. Етнолог, 15. 16-19.

Крижнар, Н. (1981). Слатко горки етнолошки филм. 28 Фестивала југословенског документарног и краткометражног филма, Београд, 54-56.

Крижнар, Н. (2006). Етнолошки филм и глобализација. XV Међународни фестивал етнолошког филма. Етнографски музеј у Београду, 7-11.

Наумовић, С. (2018). Телевизиска репортажа као визуелни изражајни стил или шта је све, и како, хтео да каже Каменко Катић, осим да ће бити кишни дан. XXVII Међународни фестивал етнолошког филма. Етнографски музеј у Београду, 15-53.

Пинк, С. (2011). Коментар о савременом значају етнографског филма у друштву. XX Међународни фестивал етнолошког филма. Етнографски музеј у Београду, 8-9.

Сречковић, С. (2007). Коментар о савременом значају етнографског филма у друштву. XVI Међународни фестивал етнолошког филма. Етнографски музеј у Београду, 6-11.

\section{Латинични изданија}

Koneska, E. (2015). Kratovo 2015, Mednarodni festival etnološkega filma, 2. - 4. oktober 2015. Slovenskega etnološkega društva, 55., 3-4., 124-125.

Koneska, E. (2015). Naško Križnar - the Pilot Steering the Development of Ethnological film in Macedonia. Vizualna antropologija - osobne iskušnje in institucionalni vidiki. Ljubljana, ZRCSAZU, 259-265.

Križnar, N. (1996). Vizualne Raziskave v Etnologiji. Ljubljana: Založba ZRC SAZU.

Ruby, J. (2000). Visualizing Culture. Chicago: University of Chicago Press. 
Ruby, J. (2015). The Teaching of Visual Anthropology at Temple University (1967 - 2004). Vizualna antropologija - osobne iskušnje in institucionalni vidiki. Ljubljana, ZRCSAZU, 29-44.

\title{
Сајтографија
}

https://boap.uib.no/index.php/jaf

JAF is publish by Bergen Open Access Publication - University publisher https://books.google.mk/books?hl=no\&lr=\&id=J9vQJ68DpvwC\&oi=fnd\&pg=PR7 $\&$ dq=journal+of+ethnographic+movies\&ots $=6 \mathrm{bNEhjyR} 8 \mathrm{~B} \& \operatorname{sig}=$ myhYTnNVwrCL2GKKWcH7y6AIjA\&redir_esc=y\#v=onepage \&q=journal\%20of\%20ethnograp hic\%20movies\&f=false

Journal of VideoEthnography

http://www.videoethno.com/

Elizabeta Koneska

\section{THE CHALLENGE OF THE VISUAL EXPRESSION AND ITS PERSPECTIVES THROUGH THE PRISM OF THE INTERNATIONAL FESTIVAL OF ETHNOGRAPHIC AND DOCUMENTARY FILMS IN KRATOVO}

\author{
Summary
}

The potential of the ethnographic film can be seen more and more in the possibility of its realization as part of the applied public and visual anthropology. The visual methods and the media are getting more accepted and popular in all the "ethnographic" disciplines, and the gap between the written and the academic anthropology is getting smaller. Also, the production of films is increasing, and the several decades long commitment of relevant authors from this field has contributed to the valorization of visual anthropology, in other words, the film is drawing closer to the theoretical level.

In our country, the only events that host presentation of ethnographic films, that disclose and feature the reality of the little common man or a community incorporated into the social, cultural, and historical context of the society, with the noble mission to narrate using voice (sound) and picture, are mostly festivals. One of them is the International Festival of Ethnographic Documentary Film in Kratovo, that has been in existence since 2012. Despite numerous positive comments and praises pertaining thereto, the festival is facing its biggest problem, in particular in the last couple of years, namely, absence of audience. The condition ensuing from the dissipation of people attending this kind of festivals, sadly, is a general declining trend not only in the whole Region but also wider. While the older generation is still in attendance, the recruiting of the younger generation is very meager. In order to bring about positive novelties and improve the situation, it is necessary to undertake more activities and introduce some changes, such as more substantive media campaigns, via the classical media, especially the social networks. Also, an improvement of the inter-institutional cooperation and inclusion of new, younger members into the relevant organizations would certainly aid in tearing down barriers and overcoming stereotypes, all of which would be conducive to a more massive popularity of this type of film, as well as the festival in Kratovo. 
The experiences from the neighboring countries of two already affirmed and internationally acclaimed manifestations, the International Festival of the Ethnographic Film in Belgrade, as well as DEF -Days of the Ethnographic Film in Ljubljana, that are also facing lack of audience, suggest involvement of a larger number of younger colleagues, as well as more intensive work on popularization via pertinent media. 